\title{
The Modern Practice of Using the Tax Regulation Instruments
}

\author{
Mariya A. Troyanskaya ${ }^{1} \&$ Yuliya G. Tyurina ${ }^{1}$ \\ ${ }^{1}$ Orenburg State University, Orenburg, Russia \\ Correspondence: Mariya A. Troyanskaya, Orenburg State University, 13, Prospekt Pobedy, 460018 Orenburg, \\ Russia. Tel: 7-919-860-2055. E-mail: m_troyanskaya@mail.ru
}

Received: August 1, 2014 Accepted: September 10, 2014 Online Published: November 14, 2014

doi:10.5539/ass.v10n23p184 URL: http://dx.doi.org/10.5539/ass.v10n23p184

\begin{abstract}
Tax regulation is carried out through a range of instruments, differing objectives impact directions of influence, mechanism of action and other characteristics. This article is merely instruments of tax regulations that apply in different countries; examples from the practice of some countries on the taxation of loss-making enterprises; pay special attention to the world practice the ratio of the level of tax exemptions and falling revenues in relation to GDP. Results of the study led to the conclusion that all countries confer taxes not only fiscal function, but also regulatory. An international survey tools tax regulation has shown that both in Russia and abroad, the most important of them are the tax rates and tax breaks. The monitoring results led to the conclusion that the tax rates established in the Russian legislation is not so high compared with the rates in developed countries. Therefore, the use of even the successful experience of other countries in order to improve the economic development of the country must be based on the detailed choice of fiscal instruments and methodologies to assess their effectiveness.
\end{abstract}

Keywords: tax regulations, tools of tax regulation, incentives, tax benefits, lost income

\section{Introduction}

Tax regulation serves two very important tasks. The first is aimed at regulating the economy, because through the tools of tax regulations have an impact on the socio-economic development of the country. The second is on the ordering of the existing tax system (Troyanskaya \& Tyurina, 2013). Improved tax regulation will enable to stabilize the socio-economic and political processes taking place in the world. This requires a detailed study of all existing tools of tax regulations, both in Russian and in the world. In order to achieve accelerated economic growth is necessary to find and implement the most efficient fiscal instruments that allow for a more rapid development of industries.

Analysis of the scientific literature (Berezin, 2010; Boranukov, 2008; Mitrofanov \& Pleshakov, 2013; Troyanskaya, 2013) showed that a large number of scholars have devoted their scientific work and taxation instruments of its implementation, at the same time, some of the problems in this sphere and remain unsolved.

\section{Method}

In academic and scientific journals have a significant number of positions of economists about the concept of "tax adjustment" (Troyanskaya, 2013). In the context of this article will not be affected by a variety of views on the scientific basis of this definition, however, we note that, under the tax regulations we understand the impact of taxes on the socio-economic system of the state, synthesizes both conscious and spontaneous beginning of state influence.

Tax regulation must comply with the state's interests in the fiscal and taxpayers' interests. Consequently, its purpose is to ensure all expenditures of state budget revenues, as well as stimulation of investment processes, the growth of the financial results of the business, resulting in growing budget revenues.

Sustainability of the economic development of the country depends on the extent to which realized its competitive advantages. The exact choice of fiscal instruments and methodologies to assess their effectiveness will allow realize these benefits. World practice known following are the most common methods of state tax regulation (Berezina, 2010):

- Postponement of tax payment,

- The investment tax credit, 
- Tax holidays,

- The tax amnesty

- Tax deductions

- Choice and change and differentiation in tax rates,

- International agreements on avoidance of double taxation,

- Changes in the composition and structure of the tax system,

- Replacement of one method or other forms of taxation,

- Change in tax incentives and rebates, which were rerouted to areas, facilities and payers,

- Full or partial exemption from taxes,

- Investment tax credits,

- Bonus depreciation.

Table 1. Tools of tax regulation

\begin{tabular}{ll}
\hline \multicolumn{2}{c}{ Tools of tax regulation } \\
\hline Effected indirectly & Effected directly \\
\hline The ratio of taxes within the tax system & $\begin{array}{l}\text { Types of taxes and fees, principles and forms of their } \\
\text { establishment } \\
\text { Tax procedures, the rights duties and functions of the } \\
\text { tax authorities }\end{array}$ \\
Pricing/base & $\begin{array}{l}\text { Administrative acts of public authorities and local } \\
\text { self-government }\end{array}$ \\
$\begin{array}{l}\text { Tax incentives: tax credits, exemptions, tax credits } \\
\begin{array}{l}\text { The distribution of the tax burden between the groups } \\
\text { of taxpayers }\end{array}\end{array}$ \\
\hline
\end{tabular}

\section{Results}

Considering the different ways the impact of taxes on the economy, it can be concluded that the instruments of tax regulations are all elements of taxation. Taxes are a set of rights and legal responsibilities of the subjects of legal relations. Legal liability is necessary for the proper performance of duties. That is, the tools of tax regulation may assume that all elements of the tax and fiscal responsibility.

One of the most important tools are the benefits of tax regulation. They are often used both in Russia and abroad. Benefits stimulate the development of the activity for which they are designed: economic activity increases in preferential activities. Tax credits help to equalize the position of economic agents, as well as stimulate the development of priority sectors (Boranukov, 2008).

Activities of organizations governed by and through the tax rates. Lowering tax rates leads to increased investment and increased production. Setting different tax rates, the state determines the differentiated approach to different types of activities. As a result, there is a stimulation little attractive activities.

It should be noted that the subjects do not practically use changes in terms of taxes and fees, as well as the investment tax credit. Often this is due to the established stringent requirements that must be completed to be able to use this tool. The main purpose of the tax authorities is to maximize tax revenue, but the provision of delays and installments not meet this problem.

Based on the fact that in Russia (Troyanskaya, 2013), and in foreign countries, the main instruments of fiscal regulation are the tax rates and tax credits in the future when considering foreign experience attention is paid to them. These methods of influencing the activities of enterprises should be used in combination.

We carry out a comparison of tax rates and exemptions of several developed countries: USA, UK, Germany, France, Russia (Table 2). First consider the tax on personal income (PIT).

Table 2 shows that in all the countries represented are provided differentiated rates of tax on personal income. 
Table 2. The tax rate in different countries

\begin{tabular}{cccc}
\hline Countries & Tax rate on personal income & Income tax rate & VAT rate \\
\hline USA & Differentiated rate $10-39.6 \%$ & Differentiated rate $15-35 \%$ & - \\
United kingdom & Differentiated rate $10-50 \%$ & $20 \%$ и $23 \%$ & $17.5 \%$ \\
Germany & Differentiated rate $0-45 \%$ & $15 \%+5,5 \%+(7-17,5 \%$ tax on trade $)$ & $19 \%$ \\
France & Differentiated rate $0-41 \%$ & $33.33 \%$ & $19.6 \%$ \\
Russia & $13 \%$ & $20 \%$ & $18 \%$ \\
\hline
\end{tabular}

In the USA, the tax rate depends on the amount of taxable income and the status of the taxpayer. Payers are divided into the following categories: single payer; spouses, filling a joint declaration; spouse, submit a separate declaration; head of household; payer - a widower. In case of contact with a few of these categories, the taxpayer chooses the one that is beneficial (USC, 2014). The maximum tax rate is $39.6 \%$, which is relative to other countries is not so great.

In France and Germany there is a system of family taxation. In this case, the family rents a declaration. Such a system is particularly advantageous when the difference of income of the spouses is high, as it leads to significant cost savings compared to taxes paid separately at the general tax regime. Relative rates should be noted that the rates are about the same range.

In the UK, the income tax on individuals charged not by the total income, and in parts "sheduls". As well as in countries previously considered tax is progressive that is dependent on the amount of income (HM Revenue \& Customs, 2014).

In Russia, the tax on personal income tax rates, there are five $(9 \%, 13 \%, 15 \%, 30 \%$, and $35 \%)$. The main personal income tax rate is $13 \%$. Different tax rates are set in relation to the types of income and in terms of categories of taxpayers (Tax Code of the Russian Federation, 2014).

Thus, the highest tax rate on personal income is set in the UK.

It should be noted that in the countries surveyed have special deductions. For example, in the United States, there are deductions for dependents and contributions to charitable organizations, medical expenses, etc.

In France, there are tax credits for dividends, energy-efficient operation, and acquisition of environmentally friendly vehicles.

In Russia, the personal income tax in the amount of the tax deduction reduces the tax base is taxed at a rate of 13\%. Russian Tax Code provides tax deductions, making it possible to return the portion of the tax that was previously paid to the budget, in connection with the exercise of certain types of expenses (e.g., property deduction in connection with the acquisition of immovable property). The following types of deductions: standard, social, and professional property.

Comparable rates and exemptions for income tax in the above countries.

Consider the specifics of taxation of corporate profits in the United States. Tax paid in stages: the corporation pays $15 \%$ for the first 50 thousand dollars of taxable income, $25 \%$ in the next 25 thousand dollars, and so on, reaching $35 \%$. It should be noted that the step has a positive effect on the taxation of small and medium enterprises, as it allows them to develop rapidly.

In France, provides a standard rate of tax on corporate profits, which is $33.33 \%$. In addition, there are reduced rates of tax: $8 \%$ for capital gains and $15 \%$ for small and medium-sized businesses with the amount of profit (Code général des impôts français, 2014).

In Germany, the corporate income tax is levied at the rate of $15 \%$. In addition, the penalty will be charged at a rate of $5.5 \%$ corporate income tax. Plus, all the companies operating in Germany are taxed on trade. Tax Rates on it establishes each municipality in the range of $7 \%$ to $17.50 \%$. The average rate of this tax is $14 \%$, so that the total corporate tax rate is approximately $30 \%$ (Abgabenordnung, 2014).

In the UK, the main rate of corporation tax is set at $20 \%$, at the same time companies engaged in oil development pay an additional corporate tax rate of $19 \%$ (HM Revenue \& Customs, 2014). 
In Russia, as well as in the UK, the basic rate of income tax is $20 \%$. In this case, $2 \%$ to the federal budget, and $18 \%$ is to the regional budget. However, the legislature regions have the right to reduce the tax rate for certain categories of taxpayers, but not more than $13.5 \%$.

In addition to the basic as well, there are special rates: $15 \%$ (income securities holders), $10 \%$ (income of foreign entities not associated with operating in Russia through a permanent establishment), 9\% (dividends, interest on certain municipal securities), $0 \%$ (interest on certain securities profit organizations engaged in medical or educational activities, profit participants of the project "Skolkovo").

In the USA, the corporate income tax has many benefits. First of all, such preferences are provided for those corporations that invest their money in the area. Just apply incentives that encourage businesses to use alternative energy sources. Of net income deducted state and local taxes on income, $100 \%$ of dividends from wholly owned local subsidiaries, interest on securities of local authorities and the state, contributions to charities. Be exempted within the accelerated reimbursement of fixed capital (depreciation) Allowance for investments on research and development activities (Mitrofanova \& Pleshakov, 2013).

The data in Table 2 shows that the highest rate of value added tax (VAT) in France. The basic tax rate is 19.6\%, slightly below the rate in Germany - 19\%, in the UK - 17.5\%, the basic rate in Russia - $18 \%$.

In all of these countries provide preferential tax rate. In this case, the full tax exemption are:

- in France: agricultural production, government agencies, private teaching, private practitioners, people involved in the work of the spiritual;

- $\quad$ in Germany: exports, the services provided by doctors, loans, cultural services provided to the public;

- in the UK: some food, books, periodicals, and other goods and services.

As well, there are reduced rates. For example, in France, food products, agricultural products and books are taxed at a rate of $5.5 \%$, and for periodicals and medicine established the rate of $2.1 \%$. In Germany, a preferential rate of $7 \%$ applies to food, books, newspapers, passenger transportation services. In the UK - 5\% for the realization of fuel, electricity, hygiene products, etc. (Keen and Lockwood, 2010).

The basic VAT rate in Russia is $18 \%$, if the operation is not included in the list of those to which the preferential rate. So, for essential goods and goods for children currently set reduced rate of $10 \%$; for exported goods - $0 \%$. It should be noted that some operations involving the sale of goods (works, services) do not form the object of taxation for VAT. Exempt from taxation the implementation of some medical goods; medical services; care for the sick, disabled and elderly; services for the conservation, acquisition and use of archives; services for the transportation of passengers; funeral services, and others.

Summing up of the surveyed countries and their tax systems, it should be noted the following:

- United States tax system with a sufficiently high tax rates has many benefits and privileges, which create favorable tax environment for small businesses and households;

- In the UK, the tax system is quite complicated, but it provides more favorable conditions for taxation. This is achieved using relatively low mandatory social security taxes, as well as by encouraging voluntary contributions and savings;

- Comparing the French tax system with the systems of the United States, Great Britain and Russia, it is possible to note a more stringent with respect to taxes on corporations and income taxes;

- Germany and France are of very high interest rates on corporate income tax, at the same time tax benefits are not so great. They are likely to use due to the need to create conditions for new enterprises, promotion of investments, which are connected with the introduction of cleaner production, saving energy, water and other resources;

- With respect to Russia should be said that in comparison with other countries, it is not as high rates of taxes. In this case, the tax system does not have enough range of benefits such as in foreign countries related to innovation.

Thus, we can conclude that the tax system of the USA and the UK, more rational, because they have a moderate tax rate and a large number of benefits, providing favorable conditions for business development.

Global tax practice under the tax burden at the macro level is the ratio of the amount recovered taxes from taxpayers, to the volume of gross domestic product (GDP). Let us analyze this relation in the previously selected countries (Table 3 ). 
Table 3. The level of tax exemptions and falling revenues in relation to GDP in $2012, \%$

\begin{tabular}{ccc}
\hline Country & Tax exemptions in relation to GDP & Lost income in relation to GDP \\
\hline USA & 26.9 & 5.9 \\
United kingdom & 39.0 & 5.5 \\
Germany & 40.6 & 4.6 \\
France & 44.6 & 3.5 \\
Russia & 36.9 & 5.2 \\
\hline
\end{tabular}

Table 3 leads to the following conclusions. Many economically developed countries of the world have reached the maximum share of tax revenue to GDP. The future growth of budget revenues in these countries is possible by providing direct proportion to tax increases on GDP growth and changes in the structure of tax revenues. Tax exemptions in Russia in 2012 amounted to $36.9 \%$ of GDP, even exceeding the figure the United States, but to the level of tax exemptions France Russia far. The leader among the countries represented is France, which has the highest proportion of tax revenues to GDP, which can be explained by a more rigid policy on corporate tax and personal income citizens, as well as the lack of a large number of benefits (Damjanovic \& Ulph, 2010).

Benefits are important in taxation in many countries. For example, the benefits of reducing the overall tax rate on corporations in the United States by about $8 \%$ in England - by 9\%. In Germany, the total tax rate on retained earnings is reduced by $16 \%$, subject to a deduction from her share of the mining tax, which is a tax on capital. It is therefore necessary to consider a fraction of the lost revenues from the provision of benefits. Big benefits in the presence of the United States confirmed a high proportion of the lost revenues in GDP. A more rigorous policy of France is visible in a relatively small fraction of the lost revenues in GDP. Russia increasingly closer to the United States as falling revenues in relation to GDP is 5.2\% (Geisler, 2013).

Russian budget losses due to the provision of benefits roughly equal 409 billion rubles a year, but it is not given an unambiguous assessment of the benefits from the implementation of the benefits of stimulating function. The government should prevent the prevalence of fiscal interests of the country at the present time on the strategy of economic growth. System of tax benefits existing in Russia, it is necessary to reform, organize, and evaluate their cost-effectiveness, as well as exercise control over the use of funds subject to preferences. In international practice, the benefits are usually installed in the industries in which the state is necessary to achieve accelerated development in the given time period. Establishment of benefits depends on the policy in the sphere of economy, science, social, and so on. N. (Becker \& Jacob, 2013).

From the above examples we can see that the tax rates in force in Russia is not so high compared with the rates in developed countries. Issue of taxation in Russia is not so much in the high-stakes, and the mentality of the people and the desire to tax authorities perform a fiscal function rather than regulatory. Due to these facts, we do not consider it appropriate to adopt the experience of leading countries and to set higher tax rates, as under the current tax system, taxpayers will try to find a loophole in order to avoid paying higher taxes. The same problem arises, and in establishing a progressive scale of taxation. Therefore, from the examples we have considered, the application of rates and exemptions in the tax systems of foreign countries, there is a particularly interesting ideas for implementation in the Russian practice.

Operating in Russia today is characterized by the absence of tax policy a solid scientific base and high fiscal. Basically, the task of increasing the income is realized by the tightening of the tax administration, although a more effective method would be to conduct activities to stimulate entrepreneurial initiative (Mitrofanova \& Pleshakov, 2013).

Enough of an issue of taxation in Russia can be considered a special under-profit companies that, for example, in Canada, not even theoretically possible. As a result of these actions we need to minimize their tax payments. Perhaps this situation is due to the fact that Russian entrepreneurs cannot keep track of what and where to spend their money.

Currently in Russia for tax purposes are counted all economically justified and documented expenses, which are aimed at generating income. At the same time, Russian companies do not seek to maximize tax profits in the account, but rather try all sorts of ways to get a loss, since according to Article 283 of the Tax Code of the Russian Federation they can transfer the resulting loss for the future over the next 10 years. 
In order to solve this problem, it would be interesting to consider the experience of Austria. In Austria, the mandatory minimum provide for the payment of corporate tax, which does not depend on the results of the company (the sum of the minimum tax is provided separately for limited liability companies and joint stock companies separately for each of the last quarter). The sum of the minimum corporate tax for newly established companies in the first year of operation is reduced. If the company gets the loss, the payment of the minimum corporate tax is still required. Its value is transferred to the future, to make a profit (Torgle, 2012).

We assume that the payment of the minimum tax would encourage companies to keep proper accounting and become profitable, because in this condition, they would still be required to pay a specified sum to the minimum tax regardless of the outcome of its activities.

Investment tax credit is widely used overseas. He got a lot of popularity in France and Spain, and is the main form of tax assistance. There is a tax credit is considered to be an effective tool for bringing government to a significant return (Besley \& Persson, 2013). However, good acting abroad, the investment tax credit in Russia is practically not working. The reason for this is the difficulty and disadvantage of its provision. To address these problems it is advisable to extend the time and ease the conditions for the loan to remake this form of benefits in an effective and valid incentive to invest.

In terms of innovation may benefit from the experience the United States to provide incentives that encourage interaction between higher education institutions and organizations engaged in joint scientific innovation.

\section{Discussion}

The study showed that the instruments of tax regulation pay attention to many scientists and economists. Thus, the tax regulation is seen as a complex effect of the tax policy of the state, since its purpose - not only the interests of the state in the fiscal activities, i.e. to ensure coverage of public expenditure budget revenues, but also the interests of the taxpayer, as well as providing the necessary conditions for welfare the whole country (Berezina, 2010). At the same time, it is to create conditions for the concentration in government financial resources that are needed to solve the problems socio-economic and scientific-technical development challenges facing the country's economy (Boranukov, 2008). Particular attention is paid to the tax incentives, characteristics and principles. The characteristics of some of the tools by which the process takes place tax regulation (Lipatova, 2011; Troyanskaya, 2013). We should also pay attention to the modern system of company taxation and ways of improving the system with the use of foreign experience, as well as the prospects of its development (Mitrofanova \& Pleshakov, 2013).

\section{Conclusion}

According to the study should be said that the country's tax confer regulatory function. Tools of tax regulations in the different countries are the same, but they have some features that are associated with different levels of economic development. That is why the rash poaching even good practice, not only cannot give the desired result, but also to create a worse economic situation. That is a sound approach is required, which will be based on an assessment of the effectiveness of the introduction of any tax mechanism.

Learning tools tax regulation has shown that both in Russia and abroad, the main instruments are the tax rates and tax breaks. The results showed that the tax rates in force in Russia are not so high compared with the rates in developed countries. Thus, in order to achieve stable economic development of the country needs a precise choice of fiscal instruments and methodologies to assess their effectiveness. At the same time, it is worth noting that in the context of this study have not been compared in detail the most deferral and installment tax payments, tax holidays and bonus depreciation. Further research will take place in this direction.

\section{Acknowledgements}

This article was prepared under a grant from the Russian Foundation for Humanities \# 14-12-56003.

\section{References}

Abgabenordnung, A. O. (2014). Germany. Retrieved from http://www.gesetze-im-internet.de/ao_1977/ index.html

Becker, B., \& Jacob M. (2013). Payout taxes and the allocation of investment. Journal of Financial Economics, 107(1), 1-24. http://dx.doi.org/10.1016/j.jfineco.2012.08.003

Berezina, O. V. (2010). Tax regulation: Concept, methods, techniques. Retrieved from http://www.tisbi.org/ home/science/journal-of-tisbi/2000/4/14/.

Besley, T., \& Persson, T. (2013). Taxation and Development. Handbook of Public Economics, 5(1), 51-110. 
http://dx.doi.org/10.1016/B978-0-444-53759-1.00002-9

Boranukov, A. H. (2008). Tax management tools for economic development. Russian Entrepreneurship, 11(122), 78-82.

Code général des impôts français. Retrieved from http://www.legifrance.gouv.fr/affichCode.do?cidTexte= LEGITEXT000006069577

Damjanovic, T., \& Ulph, D. (2010). Tax progressivity, income distribution and tax non-compliance. European Economic Review, 54(4), 594-607. http://dx.doi.org/10.1016/j.euroecorev.2009.09.003

Geisler, G. G. (2013). Federal income tax laws that cause individuals' marginal and statutory tax rates to differ. Journal of Accounting Education, 31(4), 430-460. http://dx.doi.org/10.1016/j.jaccedu.2013.08.001

Internal Revenue Code (26 USC). Date Views. Retrieved July 4, 2014, from http://www.fourmilab.ch/uscode/26usc/www/contents.html

Johannesen, N. (2010). Imperfect tax competition for profits, asymmetric equilibrium and beneficial tax havens. Journal of International Economics, 81(2), 253-264. http://dx.doi.org/10.1016/j.jinteco.2010.04.002

Keen, M., \& Lockwood, B. (2010). The value added tax: Its causes and consequences. Journal of Development Economics, 92(2), 138-151. http://dx.doi.org/10.1016/j.jdeveco.2009.01.012

Lipatov, I. V. (2011). Tools of tax regulation of the economy of the RF subjects. Taxes and Finance. Retrieved from http://www.taxfin.kz/index.php?option=com_content\&task=view\&id=812 \& Itemid $=50$.

List of countries by tax revenue as percentage of GDP. (2014). Retrieved from http://en.wikipedia.org/wiki/List_of_countries_by_tax_revenue_as_percentage_of_GDP.

Mitrofanova, I. A., \& Pleshakov, G. G. (2013). Topical application of foreign experience of corporate taxation in the Russian context. Young scientist, 9, 217-220.

Official site of the British tax office. (2014). Retrieved from http://www.hmrc.gov.uk/

Revenue, H. M., \& Customs, A. (2014). Retrieved from http://www.hmrc.gov.uk/

The Tax Code of the Russian Federation. (2014). Retrieved from http://www.zakonrf.info/nk/

Torgle, B. (2012). Tax morale, Eastern Europe and European enlargement. Communist and Post-Communist Studies, 45(3), 11-25. http://dx.doi.org/10.1016/j.postcomstud.2012.02.005

Troyanskaya, M. A. (2013). Tax regulation and tools for its implementation. In the world of scientific discovery, 11(47), 211-217.

Troyanskaya, M. A., \& Tyurina, Y. G. (2013). Evaluation of the tax regulation of certain types of investments. Economy. Taxes. Right, 3(1), 80-88.

\section{Copyrights}

Copyright for this article is retained by the author(s), with first publication rights granted to the journal.

This is an open-access article distributed under the terms and conditions of the Creative Commons Attribution license (http://creativecommons.org/licenses/by/3.0/). 